\title{
ANALISIS POTENSI PARIWISATA BENDUNGAN GONGGANG GUNA MENINGKATKAN PENDAPATAN ASLI DAERAH KABUPATEN MAGETAN
}

\author{
Elva Nuraina dan Anggita Langgeng Wijaya \\ Pendidikan Akuntansi IKIP PGRI MADIUN \\ Email: elvanuraina99@gmail.com
}

\begin{abstract}
ABSTRAK
Penelitian ini bertujuan melakukakan analisis terhadap potensi pariwisata bendungan Gonggang guna meningkatkan pendapatan asli daerah kabupaten Magetan. Bendungan Gonggang merupakan bendungan baru di kabupaten Magetan. Bendungan ini terletak didesa Gonggang Kecamatan Poncol Kabupaten Magetan Jawa Timur. Bendungan ini diresmikan tahun 2012 dan selama ini potensi pariwisata yang dimiliki oleh bendungan Gonggang belum tergali secara optimal sehingga belum memiliki kontribusi terhadap pendapatan asli daerah kabupaten Magetan. Melalui penelitian ini penulis akan melakukan analisis tentang potensi pariwisata bendungan gonggang sebagai model pengembangan pariwisata sebagai upaya meningkatkan pendapatan asli daerah kabupaten Magetan. Analisis data menggunakan pendekatan deskriptif kualitatif. Prosedur penelitian yang telah dilakukan sampai dengan tahap ini adalah identifikasi data awal, studi lapangan melalui proses observasi,wawancara dengan berbagi pihak terkait dan dokumentasi. Berdasarkan hasil analisis dapat disimpulkan bahwa: 1) Bendungan Gonggang memiliki potensi pariwisata berupa keindahan alam yang menarik para wisatawan untuk datang berkunjung, 2) Optimalisasi Bendungan Gonggan sebagai tujuan wisata dapat dilakukan dengan cara penyedian berbagai fasilitas umum yang menunjang kegiatan wisata, 3) Pengembangan potensi bendungan Gonggang dapat dapat menciptakan lapangan kerja baru dan menggerakan perekonomian masyakarat sekitar, 4) Optimalisasi optensi wisata bendungan Gonggang dapat memberikan kontribusi pada Pendapatan Asli Daerah (PAD) Kabupaten Magetan melalui penerimaan daerah dibidang pariwisata, pajak, serta retribusi daerah.
\end{abstract}

Kata kunci : bendungan gonggang, pariwisata, pendapatan asli daerah, Magetan.

\section{PENDAHULUAN}

Pelaksanaan otonomi daerah yang dititikberatkan pada daerah kabupaten dan daerah kota dimulai dengan adanya penyerahan sejumlah kewewenangan (urusan) dari pemerintah pusat ke pemerintah daerah yang bersangkutan. Penyerahan berbagai kewenangan dalam rangka desentralisasi ini tentunya harus disertai dengan penyerahan dan pengalihan pembiayaan. Sumber pembiayaan yang paling penting adalah sumber pembiayaan yang dikenal dengan istilah Pendapatan Asli Daerah (PAD) yang komponen utamanya adalah pajak dan retribusi daerah (Riduansyah, 2003).

Novalita (2007) menyatakan bahwa dalam rangka menjalankan fungsi dan kewenangan pemerintah daerah dalam bentuk pelaksanaan kewenangannya, daerah harus dapat mengenali potensi dan mengidentifikasi sumber-sumber daya yang dimilikinya. Pemerintah daerah diharapkan lebih mampu menggali sumber-sumber keuangan khususnya untuk memenuhi kebutuhan pembiayaan pemerintahan dan pembangunan di daerahnya melalui Pendapatan Asli daerah (PAD). Tuntutan peningkatan PAD semakin besar seiring dengan semakin banyaknya kewenangan pemerintahan yang dilimpahkan kepada daerah disertai pengalihan personil, peralatan, pembiayaan dan dokumentasi (P3D) ke daerah dalam jumlah besar. Untuk meningkatkan akuntabilitas dan keleluasaan dalam pembelanjaan APBD-nya, sumber-sumber penerimaan daerah yang potensial harus digali secara maksimal di dalam koridor peraturan 
perundang-undangan yang berlaku, termasuk diantaranya adalah pajak daerah dan retribusi daerah yang sudah sejak lama menjadi salah satu unsur PAD yang utama. Semakin tinggi kewenangan keuangan yang dimiliki daerah, semakin tinggi peranan PAD dalam struktur keuangan daerah, begitu pula sebaliknya.

Santoso dan Rahayu (2005) menyatakan bahwa PAD sebagai salah satu penerimaan daerah mencerminkan tingkat kemandirian daerah. Semakin besar PAD maka menunjukkan bahwa daerah itu mampu melaksanakan desentralisasi fiskal dan ketergantungan terhadap pemerintah pusat berkurang. PAD diartikan sebagai penerimaan dari sumber-sumber dalam wilayahnya sendiri, yang dipungut berdasarkan Undang-undang yang berlaku. Salah satu usaha pemerintah dalam rangka mendukung pembangunan adalah dengan mengembangkan industri pariwisata. Industri pariwisata adalah salah satu potensi sumber daya yang cukup menjanjikan untuk sumber pendapatan daerah karena dapat menciptakan lapangan kerja yang cukup besar, selain itu baik tenaga kerja formal maupun informal sangat diperlukan untuk industri ini. Dari pariwisata diharapkan diperoleh devisa bagi negara, segaligus dapat meningkatkan penghasilan asli daerah.

Setianingsih(2006) menyatakan bahwa pariwisata merupakan sutu industri yang sangat kompleks karena kegiatannya adalah kumpulan dari bermacam-macam industri yang secara bersama-sama menghasilkan barang dan jasa yang dibutuhkan wisatawan. Industri pariwisata merupakan mata rantai yang sangat panjang dari kegiatan biro perjalanan, jasa angkutan pariwisata, perhotelan, restoran, kegiatan pemanduan, kerajinan rakyat, kesenian daerah, dan lain sebagainya. Hal ini berarti pengembangan sektor pariwisata dapat menggerakkan dan memicu pertumbuhan sektor-sektor ekonomi lainnya dengan jangkauan yang sangat luas dimana sejumlah tenaga kerja akan terserap dalam kegiatan pariwisata sebagai tenaga kerja maupun yang bekerja di sektor-sektor pendukung dan semua itu akan mendorong pembangunan daerah. Dengan demikian dapat dikatakan bahwa industri pariwisata dapat memajukan dan meratakan perekonomian Negara.

Rofiq (2006) menyatakan bahwa dunia pariwisata merupakan sektor yang dapat dikembangkan dalam rangka meningkatkan Pendapatan Asli Daerah (PAD). PAD merupakan salah satu sumber penerimaan daerah yang sangat penting untuk membiayai penyelenggaraan pemerintah daerah. Oleh karena itu apabila dikelola dengan baik, sektor pariwisata dapat memberikan kontribusi yang signifikan terhadap PAD. Perkembangan sektor pariwisata secara lebih luas akan dapat memberikan multiplier effect terhadap peningkatan kesejahteraan masyarakat. Dengan adanya pariwisata, sektor rill yang ada di masyarakat dapat berkembang seperti industri kerajinan, makanan, hotel dan penginapan yang pada akhirnya bisa meningkatkan kesejahteraan masyarakat.

Kabupaten Magetan merupakan salah satu kabupaten di Jawa Kabupaten Magetan memiliki potensi sumber daya yang besar dan keindahan alam yang sangat menakjubkan.Salah satu objek pariwisata yang terkenal dari Magetanadalah Telaga Sarangan yang terletak di lereng gunung Lawu. Namun demikian peneliti mengamati bahwa ada beberapa potensi pariwisata lain yang belum dikelola dengan optimal oleh Pemerintah Daerah Kabupaten Magetan, salah satunya Bendungan Gonggang. Bendungan Gonggang merupakan bendungan baru yang terletak di Desa Gonggang Kecamatan Poncol Kabupaten Magetan. Bendungan ini baru diresmikan pada pertengahan tahun 2012 yang lalu.

Secara tata letak bendungan ini dapat dinilai unik. Bendungan ini terletak di atas pegunungan dan berposisi diantara sisi-sisi terjal pegunungan di sisi Selatan Magetan. Keindahan alam yang dimiliki oleh bendungan cukup memancing para pelancong untuk datang menikmati keindahan alam bendungan ini terutama kaum muda. Namun saat ini potensi pariwisata belum dikelola secara optimal baik oleh masyarakat sekitar maupun oleh dinas-dinas terkait di kabupaten Magetan. Bendungan Gonggang saat ini difungsikan sebagai sumber pengairan bagi daerah-daerah pertanian di sekitar kecamatan Poncol Magetan. Namun 
penulis menilai tata letak dna keindahan alam yang dimiliki oleh Bendungan ini dapat dioptimalkan sebagai daerah pariwisata unggulan Kabupaten Magetan yang diharapkan dapat mendorong perekonomian masyarakat Desa yang ada disekitar bendungan Gonggang dan sekaligus sebagai upaya meningkatkan potensi pemasukan bagiPendapatan Asli Daerah Kabupaten Magetan. Berdasar hal tersebut peneliti akan melakukan analisis tentang potensi pariwisata bendungan gonggang guna meningkatkan pendapatan asli daerah kabupaten magetan.

\section{TINJAUAN PUSTAKA \\ Pariwisata}

Pada hakekatnya berpariwisata adalah suatau proses kegiatan kepergian sementara dari seseorang atau lebih menuju tempat lain di luar tempat tinggalnya. Dorongan kepergian dikarenakan berbagai kepepntingan baik karena kepentingan ekonomi, sosial, kebudayaan, politik, agama, kesehatan, maupun kepentingan lainyang bersifat sekedar ingin tahu, menambah pengetahuan atau belajar. Menurut Undang-Undang No.9 tahun 1990 tentang kepariwisataan pasal 1 disebutkan pariwisata adalah segala sesuatu yang berhubungan dengan wisata, ternasuk pengusahaan objek dan daya tarik wisata serta usaha yang terkait di bidang tersebut.

Menurut peraturan pemerintah No.24 Tahun 1979, pariwisata adalah perwujudan dari cipta manusia, tata hidup seni budaya serta sejarah bangsa tempat atau keadaan alam yang akan mempunyai daya tarik untuk dikunjunginya. Pariwisata adalah suatu gejala sosial yang sangat kompleks, yang menyangkut manusia seutuhnya dan memiliki berbagai aspek: aspek sosiologis, aspek psikologis, aspek ekonomis, aspek ekologis, dan sebagainya. Aspek yang mendapat perhatian paling besar dan hampir merupakan satu-satunya aspek yang dianggap penting ialah aspek ekonomisnya. Dengan kata lain untuk untuk melakukan perjalanan wisata orang harus mengeluarkan biaya yang nantinya diterima oleh orang-orang yang menyelenggarakan angkutan, menyediakan berbagai jasa-jasa, atraksi dan lain-lainnya sehingga daerah yang dikunjungi wisatawan merupakan daerah yang mendapat keuntungan ekonomis yang nantinya merupakan tujuan pembangunan pariwisata (Setianingsih, 2006).

\section{METODE PENELITIAN \\ Desain Penelitian}

Desain penelitian ini menggunakan metode kualitatif dengan tujuan untuk menganalisis potensi pariwisata bendungan Gonggang guna meningkatkan Pendapatan Asli Daerah Kabupaten magetan. Penelitian kualitatif sering disebut metode penelitian naturalistic karena penelitiannya dilakukan pada kondisi yang alamiah (natural setting); disebut juga metode etnography, karena pada awalnya metode ini lebih banyak digunakan untuk penelitian bidang antropologi budaya; disebut sebagai metode kualitatif, karena data yang terkumpul dan analisisnya lebih bersifat kualitatif. (Sugiyono, 2009:8).

\section{Sumber Data Penelitian}

Sumber data dalam penelitian ini adalah data sekunder. Data sekunder adalah data yang di peroleh dari sumber eksternal yang terkait dengan obyek yang akan diteliti. Sumber data dalam penelitian ini diperoleh melalui pihak-pihak yang terkait dengan bidang ekonomi dan pariwisata kabupaten Magetan, diantaranya: Pemerintah Daerah Kabupaten Magetan, dan Dinas Pekerjaan Umum.

\section{Teknik Pengumpulan Data}

Teknik pengumpulan data menggunakan metode:

\section{Observasi}

Observasi adalah teknik pengumpulan data dimana peneliti terjun langsung ke lokasi penelitian untuk mengetahui kondisi fenomena yang menjadi pengamatan. 


\section{Wawancara}

Wawancara merupakan pengumpulan data yang sekaligus sebagai media interaksi awal yang nantinya akan mempermudah peneliti dalam melaksanakan penelitian. Sugiyono, (2009: 137) berpendapat Wawancara digunakan sebagai teknik pengumpulan data apabila peneliti ingin melakukan studi pendahuluan untuk menemukan permasalahan yang harus diteliti.

\section{Dokumentasi}

Dokumentasiadalah teknik pengumpulan data dimana peneliti memperoleh data sekunder yang disediakan oleh dinas dan lembaga terkait dengan kebutuhan data penelitian.

\section{Prosedur dan Analisis Data}

Analisis data menggunakan metode kualitatif dengan tujuan untuk meganalisis potensi Pariwisata Bendungan Gonggang yang selama ini belum dikelola secara optimal oleh Pemerintah daerah setempat dengan tujuan untuk meningkatkan kontribusi pada Pendapatan Asli Daerah Kabupaten Magetan.

\section{HASIL DAN PEMBAHASAN}

\section{Gambaran Umum Kabupaten Magetan}

Kabupaten Magetan, adalah sebuah kabupaten di Provinsi Jawa Timur, Indonesia. Ibukotanya adalah Magetan. Kabupaten ini berbatasan dengan Kabupaten Ngawi di utara, Kota Madiun dan Kabupaten Madiun di timur, Kabupaten Ponorogo, serta Kabupaten Karanganyar dan Kabupaten Wonogiri (keduanya termasuk provinsi Jawa Tengah). Kabupaten Magetan terdiri atas 19 kecamatan, yang terdiri dari 208 desa dan 27 kelurahan. Kabupaten Magetan terletak di antara 7 38' 30" Lintang selatan dan 111 20' 30" Bujur Timur. Luas Kabupaten Magetan adalah 688,85 km²,yang terdiri dari 17 wilayah kecamatan, 208 desa, 27 kelurahan, 822 Dusun/Lingkungan, dan 4575 Rukun Tetangga. uhu udara berkisar antara 16 - $20 \mathrm{C}$ di dataran tinggi dan antara 22 - $26 \mathrm{C}$ di dataran rendah. Curah hujan ratarata mencapai 2500 - $3000 \mathrm{~mm}$ di dataran tinggi dan di dataran rendah antara 1300 - 1600 $\mathrm{mm}$.

Beberapa obyek wisata terkenal di Kabupaten Magetan yang sedang dikembangkan adalah: Gunung Lawu,,Telaga Sarangan, kerajinan gamelan patihan karangrejo, Telaga Wahyu, Candi Sadon, Candi Simbatan (Beji), Puncak Lawu, Air Terjun Pundak Kiwo, Air Terjun Tirtasari, Argo Dumilah, Taman Ria Maospati, Manunggal, Pemandian Dewi Sri, Gerbang Kadipaten Purwodadi, Cemorosewu, Mojosemi Camping Ground dan Sumber Clelek Driyorejo.

Daerah wisata baru yang memiliki potensi untuk dikembangkan adalah bendungan Gonggang. Bendungan ini baru saja diresmikan oleh Mentri Pekerjaan Umum Djoko Kirmanto pada tahun 2012. Sebagai sebuah bendungan, bendungan gonggang memiliki keindahan alam yang berpotens untuk berkembang sebagai tempat wisata yang dapat berkontribusi terhadap pendapatan asli daerah (PAD) Kabupaten Magetan.

\section{Gambar Umum Bendungan Gonggang}

Di Kabupaten Magetan terutama di bagian selatan yaitu di Kecamatan Poncol, Ngariboyo dan Lembeyan dengan jumlah penduduk \pm 108.000 jiwa (dalam th 2003) sebagian besar masyarakatnya hidup dari hasil pertanian. Didaerah tersebut keadaan lahannya sangat gersang dan tandus, dimana pada musim kemarau sangat kekurangan air. Tujuan awal dibangunnya bendungan ini adalah sebagai sumber air irigasi untuk berbagai kegiatan pertanian masyarakat Magetan yang sering mengalami kesulitan air. Pemerintah Kabupaten Magetan telah melakukan langkah strategis untuk membangun waduk Gonggang, antara lain dengan melakukan studi, Pra Desain, Detail Desain, Sertifikasi Desain, Larap dan Amdal. 
Untuk pelaksanaan fisik dimulai pada ahun Anggaran 2004 yang dilaksanakan oleh Satuan Kerja Non Vertikal Tertentu Pengembangan dan Pengelolaan Sumber Air Bengawan Solo.

Bendungan Gonggang terletak pada aliran sungai Gonggang yang merupakan anak sungai Madiun dengan Daerah Aliran Sungai (DAS) seluas $12.657 \mathrm{~km} 2$ terletak di Dusun Ledok, Desa Poncol, Kecamatan Poncol, Kabupaten Magetan, Propinsi Jawa Timur. Bendungan ini sudah mulai di bangun sejak tahun 2004 dengan menghabiskan biaya sebesar Rp 109.374.877.000 (Dinas PU Kabupaten Magetan).

\section{Potensi Wisata Bendungan Gonggang}

Bendungan Gonggang pada awalnya di bangun untuk tujuan pemenuhan kebutuhan akan ketersediaan air dan irigasi. Namun setelh diresmikan pada tahun 2012 yang lalu, Bendungan Gonggang ini menampilkan daya tarik pariwisata yang disebabkan keindahan alam yang di milikinya. Lokasi bendungan yang berada di lereng gunung dengan sisi lereng yang terjal menyajikan pemandangan alam yang luar biasa. Banyak pada muda mudi dan pelancong berkunjung ke bendungan ini untuk sekedar berfoto-foto dan menikmati keindahan alam dan kesejukan wilayahnya.

Struktur alam bendungan Gonggang masih sangat alami dengan jalan naik menuju wilayah bendungan dan jalan menurun yang tajam saat menuju wilayah bendungan membuat suasana yang sangat menarik. Bendungan ini dikelilingi oleh lereng-lereng batu tinggi yang terjal. Desa Janggan dan Desa Poncol menjadi wilayah yang berbatasan langsung dengan lokasi bendungan. Pemandangan alam yang indah dan wilayah yang subur menjadikan bendungan Gonggang tempat yang menarik untuk dikunjungi. Hal ini tentu memiliki potensi yang dapat dikembangkan dalam upaya menghidupkan roda perekonomian masyarakat sekitar, pembukaan peluang kerja baru dan potensi bagi penambahan pendapatan asli daerah kabupaten Magetan.

\section{Analisis SWOT}

Upaya pengembangan bendungan Gonggang memerlukan perencanaan yang strategis untuk mengetahui kekuatan, kelemahan, peluang dan ancaman yang ada di Waduk Gonggang. Analisis SWOT digunakan untuk mengevaluasi kekuatan (strengths), kelemahan (weaknesses), peluang (opportunities), dan ancaman (threats) dalam suatu proyek atau suatu spekulasi bisnis. Analisis SWOT bendungan Gonggang sebagai objek wisata tersaji sebagai berikut.

1. Kekuatan

Hal-hal yang menjadi keunggulan bendungan Gonggang sebagai tempat wisata antara lain: Potensi alam yang baik/indah, Pemandangan yang eksotis, lingkungan di sekitar Waduk yang asri dan nyaman, sikap masyarakat yang ramah.

2. Kelemahan

Beberapa kelemahan bendungan Gonggang sebagai tempat wisataantara lain:

a. Belum diserahkannya Waduk Gonggang ke PEMKAB Magetan masih di bawah tangan PU Periaran sehingga perencanaan untuk pengembangan wisata Waduk Gonggang belum terealisasi.

b. Akses jalan yang rusak karena masih digunakan untuk sarana perjalanan truk yang memebawa material ke Waduk Gonggang

c. Belum tersedianya lahan parkir sehingga parkir masih dilakukan di pinggir jalan bahkan di bawa masuk di area Waduk

d. Kurang tersedianya sumber daya manusia yang memiliki pengetahuan dan ketrampilan dibidang pariwisata

e. Kurangnya wahana permainan dan keamanan yang perlu di tingkatkan lagi. 
f. Masih minimnya fasilitas pendukung seperti tempat makan, parkir, toilet, hotel dan villa.

3. Ancaman
a. Penanaman tanaman di pinggir waduk yang akan menebabkan erosi
b. Bencana alam tanah lonsor
c. Persaingan dengan obyek wisata sejenis
d. Kurangnya peran serta masyarakat dalam menciptakan atraksi wisata.
e. Ada potensi penentangan dari masyarakat mengingat disebelah bendungan Gonggang terdapat pondok pesantren.

4. Peluang

a. Kondisi politik yang sudah stabil pasca Pilkada di kabupaten Magetan.

b. Ada peluang untuk bekerja sama dengan pihak swasta

c. Bendungan Gonggang dapat menjadi salah satu icon pariwisata Kabupaten Magetan

d. Wisata bertambah di Kabupaten Magetan

e. Pengembangan dan perencanaan yang berkelanjutan diharapkan memberikan kontribusi positif bagi perkembangan perekonomian masyarakat sekitar dan peningkatan Pendapatan Asli Daerah (PAD)

\section{Saran Pengembangan Bendungan Gonggang}

Untuk mengembangkan Bendungan Gonggang sebagai objek wisata diperlukan beberapa pengembangan terhadap beberapa hal sebagai berikut.

1. Objek dan daya tarik wisata

Sesuai dengan rencana BAPPEDA pembagian jenis pariwisata menurut obyeknya dan untuk di jadikan daya tarik wisata di waduk Gonggang dan panorama alam disekitarnya. Disamping tujuan rekreasi/wisata alam di daerah waduk ini, maka pembangunan obyek wisata Waduk Gonggang juga bisa dimanfaatkan untuk pengembangan olah raga dan uji ketrampilan lainnya seperti Camping Graund, Outbond, sepeda gunung, dayung dan sepeda air.

2. Akomodasi

Kebutuhan yang diperlukan dalam berwisata untuk memenuhi kebutuhan akomodasi dapat berupa suatu tempat atau kamar dimana oranorang/pengunjung/wisata dapat beristirahat/ menginap/ tidur, mandi,

makan dan minum serta menikmati jasa pelayanan dan hiburan yang tersedia dpat berupa hotel, vila, penginapan (Cottage).

Pendapat yang dikumukakan oleh kepala desa poncol yaitu sebagai berikut"... pembangunan penginapan mungkin juga akan dilakukan tetapi kearah yang positif saja karena di desa poncol dekat dengan pondok pesantren besar jadi harus menyesuaikan keadaan sekitar.

3. Jalan untuk pencapaian (aksesibilitas)

Kawasan wisata waduk gonggang ini dapat ditempuh dengan melalui jalur pusat kota Magetan dengan jarak sekitar 25 kilometer kearah barat atau sarangan. Pencapaian kelokasi waduk Gonggang dapat ditempuh dengan angkutan umum yang ada diterminal Magetan. Kondisi jalan sepanjang jalur kota kelokasi wisata waduk Gonggang sudah cukup baik yaitu jalan aspal selebar 4 meter namun dengan kondisi jalan yang berliku-liku, banyak tanjakan dan turunan tajam serta badan jalan yang langsung berbatasan dengan jurang atau lembah, untuk pengembangan kedepan perlu adanya peningkatan jalan dan perbaikan untuk menyempurnakan dan meningkatakan aspek keselamatan/keamanan bagi pengendara. 
a. Sarana angkutan umum

Pelayanan angkuatan umum yang ada saat ini belum memadai, angkutan umum yang tersedia saat ini terdidri dari jenis angkutan colt dengan frekuensi terbatas serta kendaraan pribadi. Sub terminal yang terdekat berada di daerah Alastuwo dan Genilangit Kecamatan Poncol. Pengembangan sarana angkutan umum nanatinya dapat dikoordinasikan dengan kebutuhan angkutan pedesaan untuk melayani desa-desa sekitar. Dengan demikian, selain mendorong kebutuhan pariwisata, juga akan mendorong pertumbuhan desa sekitar. Untuk pengembangan mendatang idealnya perlu dikembangakan angkutan transportasi untuk wisatawan yang diadakan pada jam-jam dan hari-hari tertentu pada saat puncak musim kunjungan wisata ke waduk Gonggang.

b. Tempat Parkir

Dengan asumsi pada keadaan yang ramai pengunjung, maka kendaraan yang akan masuk diperkirakan antara lain:
1) Mobil
2) Motor
3) Sepeda
4) Kendaraan lain (dokar, dll,).

4. Fasilitas untuk pengembangan kegiatan pariwisata

Penyediaan fasilitas ini ditunjukan untuk meningkatkan kegiatan pariwisata, namun demikian tidak menutup kemungkinan untuk dapat dimanfaatkan oleh masyarakat setempat, pengembangan fasilitas untuk pengembangan pariwisata antara lain:

a. Area terbuka wisata waduk, yaitu penetapan wilayah kawasan wisata Waduk Gonggang sebagai fasilitas terbuka.

b. Fasilitas perdagangan stand dan kios makanan dan minuman, cinderamata atau souvenir (pasar wisata).

c. Fasilitas peristirahatan, membuat gazebo untuk tempat peristirahatan perjalnana wisatawan serta untuk santai menikmati pemandangan sekitar lokasi wisata.

d. Fasilitas ruang terbuka hijau

Hutan lindung wajib dilestarikan dan dihindarkan dari kerusakan akibat kegiatan bududaya manusia. Pada bagian yang mengalamai penuaan atau gundul, harus segera dihijaukan kembali.

e. Fasilitas keamanan dan pengelola

f. Fasilitas atraksi hiburan

Salah satu faktor penentu dalam mengembangkan dan menjaga agar sebuah daya tarik wisata dapat berkelanjutan yaitu adanya atraksi wisata. Atraksi wisata merupakan keseluruhan elemen baik yang merupakan ciptaan Tuhan maupun buatan manusia. Sebagai daerah tujuan wisata pedesaan, Waduk Gonggang memiliki nilai jual yang tinggi karena terdapat berbagai macam daya tarik baik berupa alam yang asri.

g. Air Bersih

Air merupakan kebutuhan yang sangat penting bagi kelangsungan hidup manusia, penduduk yang bermukim di daerah setempat telah memanfaatkan sumber air dari sumber mata air pegunungan karena banyak terdapat sumber mata air dan masyarakat membuat beberapa kelompok untuk membuat saluran air dari pegunungan.

h. Kamar Mandi dan Toilet

Sebagai sebuah daya tarik wisata yang sudah dikenal oleh wisatawan, Setiap tempat yang dikunjungi oleh wisatawan telah menyediakan fasilitas kamar mandi 
dan toilet. Fasilitas ini terletak bersebelahan dengan areal parkir. Kondisi kamar mandi dan toilet tersebut belum mencerminkan fasilitas untuk wisatawan yang mana kondisinya agak kotor dan terkesan kurang terawat. Sebagai salah satu fasilitas yang disediakan untuk kepentingan wisatawan, kebersihan toilet tersebut harus diperhatikan sehingga wisatawan yang akan memanfaatkan fasilitas ini merasa nyaman

i. Pintu Masuk

Sarana pintu masuk di daerah wisata di Waduk Gonggang saat ini belum tersedia secara memadai sehingga wisatawan yang berkunjung masih belum teratur dan belum merasa nyaman dalam melakukan kunjungan. Ini merupakan tanggung jawab dari Pemerintah Daerah guna mengembangkan potensi wisata daerah setempat.

j. Tourist Information Center

Tourist Information Center merupakan salah satu sarana promosi wisata dan juga pusat informasi penunjang wisata. Berkaitan dengan hal tersebut, Tourist Information Center belum ditemukan di daerah sekitar tempat wisata, hal inikiranya juga merupakan salah satu tugas dan tanggung besar dari stake holder yang ada dalam menunjang promosi wisata daerah setempat.

k. Tempat Sampah

Sampah merupakan salah satu masalah yang akan timbul dari sebuah aktivitas, dalam hal ini aktivitas wisata. Sampah yang ditimbulkan dari aktivitas wisata belum ada, jadi untuk masalah sampah masih bisa di tanggulangi dengan cara menyediakan tempat sampah di setiap tempat yang akan dikunjungi oleh wisatawan.

Hal yang juga perlu untuk di kembangkan dalam strategi pengembangan sarana dan prasarana pokok dan penunjang kegiatan pariwisata, dengan beberapa program antara lain: Penyediaan pintu masuk (gate entrance), Penyediaan akomodasi, Penyediaan rumah makan, Penyediaan fasilitas tempat parkir dan toilet umum, Penyediaan gardu pandang, Penyediaan ruang terbuka (open space). Strategi promosi, dengan program antara lain : Melakukan riset mengenai pasar wisata potensial dan aktual, Melakukan promosi melalui biro perjalanan wisata, dan hotel, Melakukan promosi lewat internet, majalah, eksibisi, dll, bekerjasama dengan pemerintah daerah Magetan dan Pemerintah provinsi.

Diperlukan kordinasi birokrasi dan sentuhan kebijakan pemerintah daerah misalnya dengan membentuk kelembagaan khusus yang bertugas mengelola kepariwisataan obyek wisata Waduk Gonggang, meningkatkan kualitas sumber daya manusia dengan meningkatkan potensi wista Waduk Gonggang, mengadakan penyuluhan sadar wisata kepada masyarakat sekitar. Hal yang tidak kalah pentingnya adalah memberikan pelatihan dan pemahaman bagi masyarakat sekitar agar masyarakat sekitar Bendungan Gonggang dapat menanfaatkan potensi wisata yang ada sebagai sumber penggerak perekonomian masyarakat sekitar.

\section{Kontribusi terhadap Pendapatan Asli Daerah}

Pengembangan bendungan Gonggang sebagai salah satu tujuan wisata baru di Kabupaten Magetan diharapkan dapat memberikan kontribusi positif terhadap pendapatan asli daerah di Kabupaten Magetan. Adapun beberapa potensi tersebut antara lain:

1. Bila bendungan Gonggang telah dikelola di bawah lembaga khusus semisal dinas pariwisata Kabupaten Magetan, maka akan ada potensi tambahan pemasukan pendapatan asli daerah (PAD) malalui sektor pariwisata. Para wisatawan yang masuk ke Bendungan Gonggang dikenakan tarif tertentu yang akan dapat menambah Pendapatan Asli Daerah kabupaten Magetan. 
2. Potensi lain yang dapat digali adalah pemasukan dari sektor parkir kendaraan. Para wisatawan yang berkunjung ke bendungan Gonggang pasti memakai kendaraan roda dua atau roda empa, sehngga ada potensi memperbesar PAD melalui pemasukan parkir.

3. Jika daerah ini berkembang menjadi tempat wisata, tentu akan ada banyak pedagang yang berjualan di sekitar bendungan Gonggang. Hal ini adalah potensi bagi pemasukan PAD melalui retribusi harian para pedagang dan pemasukan Negara dari segi pajak penghasilan para pedagang

4. Jika hotel, restoran dan villa dapat didirikan di sekitaran Bendungan Gonggang tentu ada potensi pemasukan PAD dari sisi pajak hotel dan restoran serta pajak reklame.

Pengembangan bendungan Gonggang menjadi tempat tujuan wisata memerlukan peran aktif semua pihak. Melihat besarnya potensi alam yang dimiliki tentunya pemerintah daerah harusberperan secara aktif. Perekonomian masyarakat sekitar akan ikut terdampak secara positif bila bendungan Gonggang menjadi tempat wisata umum. Akan ada banyak lapangan kerja baru tercipta. Masyatakat sekitar bisa ikut berjualan di sekitar bendungan. Ada potensi untuk menjual produk pertanian sekitar melalui paket wisata. Hal yang integrated dengan kegiatan di tempat wisata akan memberikan kontribusi positif bagi PAD kabupaten Magetan. Maskipun untuk menuju tahap tersebut masih membutuhkan proses yang pajang, partisipasi masyarakat dan sentuhan kebijakan dari Pemerintah Daerah Kabupaten Magetan.

\section{KESIMPULAN DAN SARAN}

\section{Kesimpulan}

Berdasarkan pembahasan pada bagian sebelumnya dapat disimpulkan bahwa :

1. Bendungan Gonggang memiliki potensi pariwisata berupa keindahan alamnya yang sangat indah. Hal ini merupakan daya tarik dan keunggulan yang perlu untuk dikembangkan sebagai upaya mengembangkan Bendungan Gonggang sebagai destinasi wisata baru di Kabupaten Magetan.

2. Optimasasi Bendungan Gonggang sebagai tempat wisata dapat dilakukan dengan cara melengkapi Bendungan Gonggang dengan fasilitas pendukung yang memadai, seperti tempat parkir, hotel, restoran, tempat ibadah, tempat outbond, dll.

3. Bendungan Gonggang memiliki potensi pariwisata yang dapat memberikan kontribusi pada Pendapatan Asli Daerah (PAD) Kabupaten Magetan. Bendungan Gonggang idealnya dikelola dibawah lembaga khusus semisal dinas pariwisata kabupaten Magetan agar kontribusi terhadap PAD dapat digali dengan optimal.

4. Pengembangan potensi bendungan Gonggang dapat membuka lapangan kerja baru bagi masyarakat sekitar yang memberikan dampak positif sebagai upaya mengurangi pengangguran di Kabupaten Magetan.

5. Bendungan Gonggang memberikan potensi kenaikan PAD dari sisi parkir, retribusi pedagang, pajak hotel dan restoran, pajak reklame, serta pajak penghasilan pedagang.

\section{Saran}

Beberapa saran yang bias diberikan dalam penelitian ini antara lain:

1. Perlu dilakukan riset lanjutan untuk mengetahui dan mengoptimalkan potensi pariwisata Bendungan Gonggang di Kabupaten Magetan.

2. Optimalisasi potensi wisata Bendungan Gonggang memerlukan kerjasama dari semua pihak terutama dari masyarakat sekitar dan adanya sentuhan kebijakan yang mendukung dari pemerintah daerah kabupaten Magetan.

3. Pemerintah Kabupaten Magetan dapat memberikan kesempatan masyarakat yang memiliki potensi untuk berwirausaha di sekitar Bendungan Gonggang, sehingga keberadaan bendungan Gonggang betul-betul dapat menggerakan ekonomi masyarakat setempat. 
4. Optimalisasi Bendungan Gonggang sebagai destinasi wisata baru di Kabupaten Magetan memiliki potensi untuk menambah pendapatan asli daerah (PAD) kabupaten Magetan, penciptaan lapangan kerja baru dan dapat menumbuhkan perekonomian masyarakat sekitar.

\section{DAFTAR PUSTAKA}

Lee, Chow Ging. 2012. Tourism, trade, and income: evidence from Singapore. Anatolia-An International Journal of Tourism and Hospitality Research. Vol. 23, No. 3, November 2012, 348-358.

Moleong. 2012. Metoda Penelitian Kualitatif Edisi Revisi. Bandung: Remaja Rosda Karya.

Novalita, Betta Sari. 2007. Peranan Pajak Daerah dalam Meningkatkan Pendapatan Asli Daerah Kabupaten Bogor. www. gunadarma. ac.id

Riduansyah, Mohammad. 2003. Kontribusi Pajak Daerah Dan Retribusi Daerah Terhadap Pendapatan Asli Daerah (Pad) Dan Anggaran Pendapatan Dan Belanja Daerah (Apbd) Guna Mendukung Pelaksanaan Otonomi Daerah (Studi Kasus Pemerintah Daerah Kota Bogor). MAKARA, SOSIAL HUMANIORA, VOL. 7, NO. 2

Rofiq, Ainur. 2006. Peningkatan Peran Infokom dalam Mempromosikan Pariwisata Daerah. Workshop peningkatan kapasitas anggota DPRD kota Malang.

Oka. A. 1985. Pengantar Ilmu Pariwisata. Bandung : Angkasa.

Pemerintah Republik Indonesia. Undang-Undang No.9 tahun 1990

Pemerintah Republik Indonesia. UU No. 32 Tahun 2004

Santosa, Purbayu Budi dan Retno Fuji Rahayu. 2005. Analisis Pendapatan Asli Daerah (PAD) Dan Faktor-Faktor Yang Mempengaruhinya Dalam Upaya Pelaksanaan Otonomi Daerah Di Kabupaten Kediri. Dinamika Pembangunan Vol.2 No.1

Setianingsih, Wahyu. 2006. Pengembangan Obyek Wisata Serulingmas Sebagai Salah Satu Sumber Pendapatan Asli Daerah Kabupaten Banjarnegara. www.unnes.ac.id

Sitamorang, Victor, M. 1994. Hukum Administrasi Pemerintahan di Daerah. Jakarta: Sinar Grafika

Sugiyono. 2009. Metode Penelitian Pendidikan. Bandung: Alfabeta.

Yuningsih, Nining. 2005. Peningkatan Pendapatan Asli Daerah (PAD) Melalui Pengembangan Potensi Obyek Wisata Pantai Pangandaran Di Kabupaten Ciamis Jawa Barat. www.unnes.ac.id

www.bps.go.id

www.surakarta.go.id

www.yosin.wordpress.com 